\title{
Combined hamartoma of the retina and retinal pigment epithelium associated with optic coloboma
}

This article was published in the following Dove Press journal:

Clinical Ophthalmology

12 March 20II

Number of times this article has been viewed

\section{Nadyr Antonia Damasceno \\ Eduardo F Damasceno}

Abstract: The authors relate an uncommon case of combined hamartoma of the retina and retinal pigment epithelium associated with optic coloboma.

Keywords: combined hamartoma of the retina and retinal pigment epithelium, benign tumor, visual loss, optic nerve coloboma

\section{Introduction}

Combined hamartoma of the retina and retinal pigment epithelium is a benign tumor that may involve pigment epithelium, and vascular and glial tissue of the retina to varying degrees. ${ }^{1}$ It may cause significant visual loss and simulate choroidal melanoma and other intraocular tumors. ${ }^{2}$

\section{Case report}

The purpose of this report is to describe a rare case of combined hamartoma associated with optic coloboma in the fellow eye. A 24-year-old man presented with visual acuity of 20/20 in the right eye and 20/400 in the left eye as per the Snellen chart. In the fundus of the right eye, there were two nonpigmented nodular lesions, one placed close to the optic disc and the other in the temporal retina (Figure 1 above). In the left eye, there was a large excavation placed inside the optic disc tissue (Figure 1 below).

Fluorescein angiography showed hyperfluorescence in the right eye's lesions (Figure 1 above). The same evaluation in the left eye demonstrated optic disc coloboma (Figure 1 below). In the ocular ultrasound, the lesion close to the optic disc in the right eye was elevated and dense (Figure 2).

\section{Discussion}

Combined hamartoma of the retina and retinal pigment epithelium has been occasionally associated with systemic disease such as neurofibromatosis and tuberous sclerosis. There were various ocular abnormalities associated with combined hamartoma such as choroidal neovascularization, secondary epiretinal membrane with macular hole formation, X-linked juvenile retinoschisis, optic nerve head pits, and optic nerve head drusen. ${ }^{1}$ Combined hamartoma are almost always a solitary, unilateral tumor, and located close to the optic disc in $76 \%$, in the macula in $17 \%$, and in the peripheral retina in only $7 \% .^{3}$ Visual acuity varies with the location of the lesions, secondary macular distortion (epiretinal membrane, macular hole, choroidal neovascularization), and vitreous hemorrhage. The nodular lesions of posterior pole
Correspondence: Eduardo F Damasceno Rua do Bispo 230//02, Rio de Janeiro, RJ, Brazil 2026I-066

Tel +55 2I 35634467

Fax +55 2I 25687728

Email e_damasceno@yahoo.com 

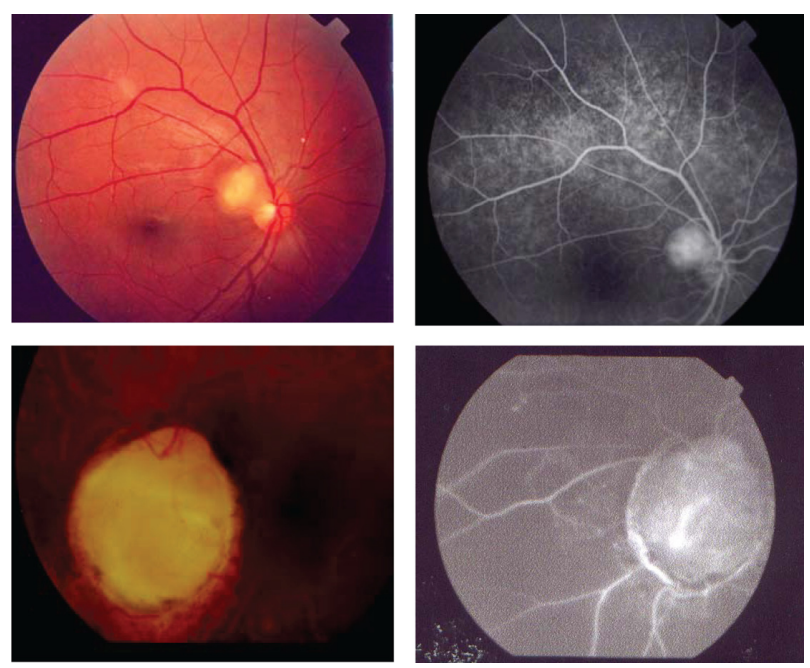

Figure I Color retinography - right and left eye and fluorescein angiography - late phase - right and left eye.

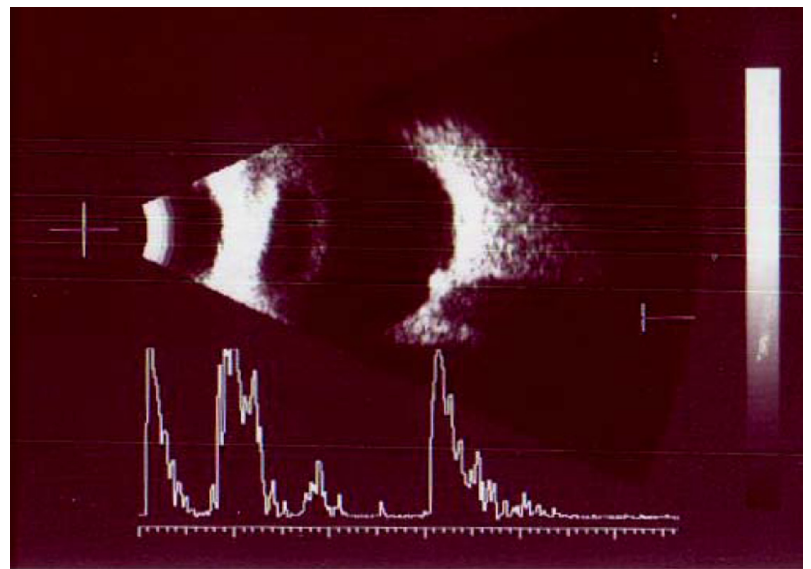

Figure 2 B ultrasound - nodular lesion - right eye. could vary different amounts of retinal pigment, vascular tissue, and glial components. In this case, the combined hamartoma had a low pigmentation and was associated with an optic coloboma. The main reason for this association is considered incidental and makes this an uncommon case. The literature reports little manifestations involving the optic disc. ${ }^{4}$ As recommended by the literature, the patient was observed through periodical follow-up. ${ }^{5}$

\section{Disclosure}

No conflicts of interest were declared in relation to this paper.

\section{References}

1. Elliot D, Schachat AP. Combined hamartoma of the retina and retinal pigment epithelium. In Ryan SR, editor. Retina. St. Louis, MO: Mosby Ed. 2001:640-646.

2. Schachat AP, Shields JA, Fine SL, et al. Combined hamartomas of the retina and retinal epithelium. Ophthalmology. 1984;91(12):1609-1615.

3. Font RL, Moura RA, Shetlar DJ, Martinez JA, Mcpherson AR. Combined hamartoma of sensory retina and retinal pigment epithelium. Retina. 1989;9(4):302-311.

4. Harper CA, Gole GA. Combined hamartoma of the retina and RPE: an unusual cause of the dragged disc appearance. Aust NZ J Ophthalmol. 1986;14(3):235-238.

5. Avitabile T, Franco L, Reibaldi M, Pulvirenti M. Combined pigment epithelial and retinal hamartomas: long-term follow-up of three cases. Can J Ophthalmol. 2007;42:318-320.
Clinical Ophthalmology

\section{Publish your work in this journal}

Clinical Ophthalmology is an international, peer-reviewed journal covering all subspecialties within ophthalmology. Key topics include: Optometry; Visual science; Pharmacology and drug therapy in eye diseases; Basic Sciences; Primary and Secondary eye care; Patient Safety and Quality of Care Improvements. This journal is indexed on

\section{Dovepress}

PubMed Central and CAS, and is the official journal of The Society of Clinical Ophthalmology (SCO). The manuscript management system is completely online and includes a very quick and fair peer-review system, which is all easy to use. Visit http://www.dovepress.com/ testimonials.php to read real quotes from published authors. 